\title{
Contribution of Emotional Intelligence and Parental Social Support in Student Learning Achievement
}

\author{
Irsal Hadi ${ }^{*}$, Netrawati ${ }^{2}$ \\ 1,2 Universitas Negeri Padang \\ ${ }^{*}$ Corresponding author, e-mail: irsalhadi81@gmail.com
}

\begin{abstract}
This study aims to analyze (1) learning achievement, emotional intelligence and social support of parents, (2) the contribution of emotional intelligence and social support both individually and collectively to student achievement behavior. This research uses descriptive quantitative method. The study population was 436 students of SMK Country 3 Padang. The research sample was 209 students who were selected by purposive sampling technique. The instrument uses a scale of emotional intelligence, and social support from parents and the results of the students' mid-semester value recap. The research data were analyzed using descriptive statistics, simple regression, multiple regression. The results of the study proved that: (1) emotional intelligence contributed $31.5 \%$ to student achievement, (2) parents' social support contributed $27.6 \%$ to student achievement, (3) emotional intelligence, shared parent social support contributed on student achievement as much as $33.4 \%$. The implication of the results of this study can be used as input for making guidance and counseling service programs in improving student learning achievement.
\end{abstract}

Keywords: Emotional Intelligence, Parental Social Support and Learning Achievement.

How to Cite: Hadi, I., Netrawati, N. (2020). Contribution of Emotional Intelligence and Parental Social Support in Student Learning Achievement. International Journal of Applied Counseling and Social SciencesI. 2 (1). pp. 55-66, DOI: https://doi.org/10.24036/005399ijaccs

\section{Introduction}

Emotional intelligence is a set of prowess that allows us to make our way through a complicated world, covering the personal, social and defense aspects of all intelligence, mystery-filled common sense and sensitivity that function effectively on a daily day. According to Soefandi Pramudya (2009) emotional intelligence is a person's ability to manage his emotional life with intelligence and express it through self-awareness skills, self-control, self-motivation, empathy and social skills. Emotional intelligence or commonly referred to as EQ as a set of social intelligence that involves the ability to monitor social feelings involving abilities in others, sorting things out and using this information to guide the thoughts and actions of Salovey Mayer (Uno, 2010). Emotional Qoutient (EQ) refers to the ability to recognize our own feelings and the feelings of others, the ability to motivate ourselves and in relation to others. Emotional intelligence is the ability to motivate one another, endure frustration, control impulses, not exaggerate pleasure, regulate mood, keep stress from crippling thinking abilities, empathize (Goleman, 2007). So it can be concluded that emotional intelligence is the ability to motivate 
one's self and the feelings of others, the ability to motivate one's self and organize well the emotions that arise in him and his relationship with others.

There are two factors that can affect a person's emotional intelligence (Goleman, 2007) namely: (1) the family environment, where the family environment is the first school in emotional learning. Parents are the first subject whose behavior is identified by the child then internalized which will eventually become part of one of the child's personalities. Parents who have high emotional intelligence will understand the feelings that the child has. Parental involvement is linked to school achievement, emotional, and adjustment during schooling in the child. Parental attention and support have a role to play in determining how to give responsibility to children in any way. (2) non-family environment, called non-family environment, namely community environment and educational environment. Both are other factors that can affect a person's emotional intelligence.

Parenting is the first social environment that students encounter in the real world. The success of education is also the responsibility of the parents. Parents have a very important role in their children's education process. Parents are also responsible for their children's learning progress. According to Thomas and Rollins (in Lestari, 2013) parental support as an interaction developed by parents characterized by care, warmth, approval, and various positive feelings of parenthood towards their child. Then, according to Tarmidi and Rambe (2010) parental support is the most important social support system in adolescence. When compared to other social support systems, parental support is associated with student academic success, positive self-image, self-esteem, confidence, motivation, and mental health.

Sarafino and Smith (1997) share aspects of parental support, namely (1) Emotional Support, where a form of support is expressed through positive feelings in the form of empathy, attention, and concern for other individuals. (2) Esteem Support, the support of this award occurs through expressions, awards or positive assessments for individuals, encouragement to progress and encouragement, as well as individual positive comparisons with others. (3) Tangible or Instrumental Support, is a support that can be realized in the form of direct assistance. And (4) Informational Support, this support is expressed in the form of providing advice or advice, appreciation, and providing feedback on what individuals are doing. Parental support can be manifested into various things and one of them is providing support in children's learning achievements. Learning achievement is the perfection that a person achieves in thinking, feeling and doing. Learning achievement is said to be perfect when it has three aspects, namely cognitive, affective and psychomotor, on the contrary it is said that achievement is not satisfactory if a person has not been able to meet the target of the criteria (Sudjana, 1996). Furthermore, according to Nurkencana Sunartana (1992) said learning achievement is called actual ability obtained by a person after learning, a potential skill (potencial ability) that is a basic ability in the form of disposition owned by the individual to achieve achievement.

To achieve optimal learning achievement can be influenced by factors in the learner (internal) and factors from outside the learner (external) (Shah, 2003). Factors that rice from within are (1) biological factors, such as physical health that marks the fitness level of the organs and joints can affect the spirit and intensity of learners in following the lesson. (2) biological factors, which are divided into intelligence, emotional intelligence, talent, and motivation. Then the factors that are from outside the self are, (1) the social environment, there are parents and families, schools, and communities. (2) nonsocial environment, namely school building and its location. From these three discussions about emotional intelligence, parental social support and learning achievements above. It can be concluded that emotionally determines the intellectual development of the child gradually, meaning that reciprocally cognitive factors are also involved in emotional development. Thus, between EQ and achievements can not be separated roles with each other. The existence of EQ is very supportive of one's achievements (Uno, 2010).

Ellis, Thomas Rollins (Sucipto, 2017) explains parental support is an interaction developed by parents characterized by care, warmth, consent, and various positive feelings of parent towards child.Then Slameto (2010) explained that family is the first and forest educational institution. Parents 
(father and mother), become primary educators and first share their children. Therefore, as a parent should be able to help and direct the child in being good in order to conform to the prevailing norms in his environment and provide informal education to help the growth and development of children. Student learning activities are quite complex processes and involve various parties in order to achieve learning objectives. Student learning activities have been very carefully designed by the government through the curriculum implemented by the school. BK as an integral part and inseparable in learning activities in schools.

Prayitno (2013) states that various services that can be provided by counseling teachers in schools such as orientation services, information services, placement and distribution services, content mastery services, individual counseling services, group guidance services, group counseling services, consulting services, mediation services, and advocacy services. Through BK services in schools, students are expected not only to focus on mastering subject matter. Students also need services that are psychoeducational. The presence of BK provides professional services that can develop students' self-potential which includes the fields of personal, learning, social, and career development as a whole and optimally (Permendikbud No.111 of 2014). BK teachers / counselors as the main implementers of BK services have a vital role to help students improve emotional intelligence, high parental support and high student achievement (KES). Furthermore, the counselor also plays a role in dealing with students' low emotional intelligence, low parental support, and low learning achievement of students (KES-T). In connection with parental support, the counselor can establish good communication with parents. students to work together to provide optimal support to students. Thus, through the services provided by BK teachers / counselors through various types of BK support services and activities, it is hoped that the learning achievement of students can be achieved.

\section{Method}

The research was conducted using descriptive correlational quantitative methods. The population of this study was 436 students of SMK Country 3 Padang and 209 research samples. The sample was selected by purposive sampling technique. The instrument used was a scale of emotional intelligence with a reliability of 0.743 , and social support of parents with a reliability of 0.724 and the results of the students' mid-semester value recapitulation. The research data were analyzed using descriptive statistics, simple regression and multiple regression

\section{Results and Discussion}

From the results of the administration of instruments sufficient number of samples of 209 respondents. The research data included variable emotional intelligence (X1), parental social support $(\mathrm{X} 2)$, and learning achievement $(\mathrm{Y})$. following the description, in the aspect of emotional intelligence (X1) is in the moderate category of 112 people with a percentage of 53.3\% Furthermore students who have high category emotional intelligence as many as 84 people with a percentage of $40.0 \%$. students who have very high category emotional intelligence as many as 11 people with a percentage of $5.3 \%$. Furthermore, emotional intelligence in the low category amounted to 3 people with a percentage of $1.4 \%$ and no students whose emotional intelligence was very low.The results of the analysis give an idea that the importance of the efforts of BK teachers / school counselors to always increase the emotional intelligence of students, especially in aspects of the medium category. BK Teachers/Counselors can provide understanding to students to improve achievement, and with these efforts it is expected that students can achieve better learning achievements. The description of emotional intelligence is summarized into table 1 below: 


\begin{tabular}{|c|c|c|c|}
\hline Interval Score & Category & Frequency & $(\%)$ \\
\hline $148-175$ & Very high & 10 & 4,8 \\
\hline $120-147$ & High & 84 & 40 \\
\hline $92-119$ & Moderate & 112 & 53,3 \\
\hline 64-91 & Low & 3 & 1,4 \\
\hline$\leq 63$ & Very low & 0 & 0 \\
\hline \multicolumn{2}{|c|}{ Total } & 209 & 100 \\
\hline
\end{tabular}

Then the aspect of parental social support (X2) in general is in the moderate category of 123 people with a percentage number of $58 \%$, in the high category as many as 2 people with a percentage of $1.0 \%$, in the low category of 80 people with a percentage of $38.1 \%$ and in a very low category of 4 people with a percentage of $1.9 \%$. The results of the analysis showed that the social support that parents provide to students on average can be said that students have received social support from parents, be it instrumental support, emotional support, information support and support awards provided by parents to students. The description of parental social support is summarized into table 2 below:

Table 2.Distribution of Frequency and Percentage of Parental Social Support $\left(\mathrm{X}_{2}\right)$

\begin{tabular}{cccc}
\hline Interval Score & Category & Frequency & $(\%)$ \\
\hline $127-150$ & Very high & 0 & 0 \\
$102-126$ & High & 2 & 1 \\
$77-101$ & Moderate & 123 & 58,6 \\
$52-76$ & Low & 80 & 38,1 \\
$\leq 51$ & Very low & 4 & 1,9 \\
& & 209 & 100 \\
\hline
\end{tabular}

Furthermore, the aspect of learning pretasis $(\mathrm{Y})$ in general is in the medium category of 86 students with a percentage of $41.0 \%$, in the high category of 81 people with a percentage of $38.6 \%$, in the very high category as many as 10 people with a percentage of $4.8 \%$, in the low category of 28 people with a percentage of $13.3 \%$ and 4 people in the very low category with a percentage of $1.9 \%$. The description of learning achievement is summarized into table 3 below:

Table 3.Distribution of Frequency and Percentage of Learning Achievement $(\mathrm{Y})$

\begin{tabular}{cc}
\hline Category & Range \\
\hline Verry Good & $86-100$ \\
Good & $71-85$ \\
enough & $56-70$ \\
not good & $\leq 55$ \\
\hline
\end{tabular}

After the research results of the three variables were carried out test analysis requirements through normality test, linearity test and multicolinearity test. Widiyanto normality test (2013) revealed the guidelines used in normality test using Kolmogorov-Smirnov test which is comparing Asymp coefficient. Sig. or P-value with a significance of 0.05.To avoid errors in the calculation manually the calculation using the help of SPSS. The results of processing are summarized into the following table: 
Table 4.Results of Emotional Intelligence Data Normality Test (X1), Soisal Parental Support (X2) and Learning Achievement (Y)

\begin{tabular}{cccc}
\hline Variable & Asymp. Sig & Significance & Description \\
\hline Emotional Intelligence $\left(\mathrm{X}_{1}\right)$ & $0,, 657$ & 0,05 & Normal \\
Parental Social Support $\left(\mathrm{X}_{2}\right)$ & 0,732 & 0,05 & Normal \\
Learning Achievement $(\mathrm{Y})$ & 0,635 & 0,05 & Normal \\
\hline
\end{tabular}

All three variables have Asymp's score. Sig. greater than the set level of significance (0.05). That is, the data from the three variables is distributed normally.

Linearity test Linearity test in this study using regression line equation / double regression. If $\mathrm{F}$ Count $>$ F Table at the level of significance $\alpha=0.05$, and if the value of deviation linearity significance is small from 0.05, then it can be said linear (Yusuf, 2013). Avoiding errors in calculations manually, calculations use the help of SPSS programs. The results of data linearity testing can be seen in the following table:

Table 5.Test Results of Emotional Intelligence Linearity (X1), Soisal Parental Support (X2) and Learning Achievement $(\mathrm{Y})$

\begin{tabular}{ccccc}
\hline Variable & F & Linearity & Level Significance & Conclusion \\
\hline $\mathrm{X}_{1}-\mathrm{Y}$ & 4,963 & 0,000 & 0,05 & Linier \\
$\mathrm{X}_{2}-\mathrm{Y}$ & 3,638 & 0,000 & 0,05 & Linier \\
\hline
\end{tabular}

Linearity test results showed variable emotional intelligence (X1) and parental social support (X2) to learning achievement $(\mathrm{Y})$ with a Linearity value of $0.000<$ a significance of 0.05 . This result gives the meaning that the data of each variable is independent (free) linear against the dependent variable (bound).

Multicolinearity Test Multicolinearity test of research conducted by looking at the amount of Variance Inflation Factor (VIF) value for each predictor, to be free from symptoms of multicolinearity VIF value is below 10 (Widiyanto, 2013). Avoiding errors in calculation manually, then the calculation using the help of SPSS 22.0 program. According to the results of the analysis using SPSS 22.0 program can be seen the results in the following table:

Table 6. Multicolinearity Test Results of Emotional Intelligence (X1), Soisal Parental Support (X2) and Learning Achievement (Y)

\begin{tabular}{cccc}
\hline Variable (Constant) & Tolerance & VIF & Description \\
\hline $\mathrm{X}_{1}$ & 0,622 & 1 & No multicolinearity \\
$\mathrm{X}_{2}$ & 0,625 & 1 & occurred \\
\hline
\end{tabular}

Based on the results of the calculation of the table, it can be known that the VIF value of emotional intelligence is 1,000 and the VIF value of parental social support is 1.00. Thus both VIFs are smaller than 10. That is, there is no multicolinearity between emotional intelligence and parental social support.

Furthermore, to find out the similarities of regression of emotional intelligence and parental social support to student learning achievement behavior is summarized into the following table: 
Table 7.Results of Analysis of Variable Double Regression Equations of Emotional Intelligence (X1), Social Parental Support (X2) and Learning Achievement (Y)

\begin{tabular}{llccc}
\hline \multirow{2}{*}{ Model } & \multicolumn{2}{c}{$\begin{array}{c}\text { Unstandardized } \\
\text { Coefficients }\end{array}$} & $t$ & Sig. \\
\cline { 3 - 4 } & & \multicolumn{2}{c}{$\mathbf{B}$} & \\
\hline $\mathbf{1}$ & (Constant) & 8,295 & 1,624 & 0,001 \\
& emotional intelligence & 0,257 & 4,216 & 0,000 \\
& parental social support & 0,134 & 2,368 & 0,004 \\
\hline
\end{tabular}

Dependent Variable: Learning Achievement

The results of the analysis shown in table 7, showed that the constant value obtained was 8,295 with the coefficient value of regression (B) to learning achievement $(\mathrm{Y})$ of the emotional intelligence variable (BX1) of 0.257 and the parental social support variable (BX2) of 0.134. Based on these results, the similarities of regression of emotional intelligence and social support of parents to learning achievement can be described as follows:

$$
\begin{aligned}
& \widehat{Y}=a+b X_{1}+b X_{2} \\
& \widehat{Y}=8,295+0,275\left(X_{1}\right)+0,134\left(X_{2}\right)
\end{aligned}
$$

The results of the analysis showed that learning achievements in SMK Country 3 Padang need to be improved. Learning achievement is the perfection that a person achieves in thinking, feeling and doing. Learning achievement is said to be perfect when it has three aspects, namely cognitive, affective and psychomotor, on the contrary it is said that achievement is not satisfactory if a person has not been able to meet the target of the criteria (Sudjana, 1996). While Winkel (2009) explained that learning achievement is a change in the field of cognitive, sensory-motor, dynamic-affective fields, and resulting in humans changing in their attitudes and behaviors.

Slameto (2010) explained that the factors that influence learning achievement are internal factors and external factors. Factors from within are: 1) intelligence, 2) interest, 3) talent, 4) motivation, while external factors are: 1) family circumstances, 2) school circumstances, 3) community environment. This is in accordance with the opinion of the Shah (2005) explaining the factors that affect learning achievement. To achieve optimal learning achievement, influenced by factors in the learners (internal) external factors of learners internal factors include physiological factors, emotional intelligence psychological factors, intelligence, talent, motivation, while external factors include the social environment consisting of parents and families, schools, communities, and non-social environments. Furthermore Ahmadi Widodo (2008) suggested that the factors that influence learning achievement are two, namely: classified as internal factors are: physical factors (physiology) both congenital and obtained. these factors include vision, hearing, body structure, and so on. psychological factors both innate and obtained consist of: intellectual factors that include potential factors, namely intelligence and talent. Real proficiency factors are achievements that have been possessed.non-intellectual factors, namely certain personality elements such as attitudes, habits, interests, needs, motivations, emotions, self-adjustment.factors of physical and psychic maturity. spiritual or security environmental factors.as for external factors, are social factors (family environment, school environment, community environment, group environment.

Soejanto (1991) students' self-readiness is very important to achieve success in learning activities. The success of students doing readiness before entering the lesson can determine the success of students in learning, so it will affect the student's learning achievement. The success of a lesson depends on how the learning process is experienced by the students. Murphy $(2009, \mathrm{p} .22)$ stated that factors that influence achievement factors that affect learning achievement include educators, students, and educational environments that reflect a culture of competence. Educator factors can be seen from the performance of teachers, student factors can be seen from the motivation of achievement and discipline of learning, the educational environment can be seen from school facilities and infrastructure, the 
implementation of prakerin and parental support.Many factors behind student learning achievement such as Thaib's opinion, E. N. (2013) emotional intelligence can be expressed as one of the important factors that should be possessed by students who have a need to achieve better learning achievement in school and prepare them to face the real world.

This is supported by the research of Yanti Oktavia Netrawati (2019) with the title of emotional intelligence relationship with the learning outcomes of students at SMP Negeri 13 Padang with the results of her research is there is a correlational corfisien of 0.526. It can be interpreted, the higher the emotional intelligence of the students, the higher the learning outcomes obtained by students. Then the results of Alwiyah research (2012) showed that there is an influence of emotional intelligence on the learning achievement of learners with a free influence of $41.01 \%$. David (2012) showed the influence of emotional intelligence on the learning achievements of learners with a free influence of $51.00 \%$.

In addition to emotional intelligence learning achievement is also influenced by external factors including parental social support. The results showed that parents' social support contributes to students' learning achievements. The support provided by parents will provide a positive thing for the child. Social support should be more considered because at this time as we already know that in adolescence children will have mature social growth. Often in this adolescence the child begins to have thoughts that are difficult to manage and tend to be more selfish. Because in adolescence will develop his social life with peers. The child will divide his time with new things he likes.

In this case parental social support is needed to control the extent of the child's development. So as not to go the wrong way. According to sarafino (1997) social support refers to the comfort, care, appreciation, or bantua felt by the individual received from others or his group. Parental support is associated with adolescent academic success. Positive self-image, self-esteem, confidence, motivation, and mental health. Thus social support as above, then the child will feel his parents can provide comfort, and care, then the child will not be difficult to manage.

This is supported by the research of Saragi., Iswari., Mudjiran. (2016) that parental support had a $31.1 \%$ effect on students' learning achievements the remaining $68.9 \%$ was determined by other factors. Furthermore, the results of this study were strengthened by the results of Chyntia research (2019) where the results showed that parental social support directly affects student learning achievement.

From the description above, it can be concluded that to improve learning achievement is needed emotional intelligence and social support of parents. There are many ways to improve student learning achievement. An efficient way of learning starts from yourself, namely learning regularly, disciplined, and concentrating when taking lessons. Therefore, to help improve student learning achievement in order to be more optimal, these factors should be enabled in a masksimal way so that eventually the student's learning achievements will be better. four steps that can be taken by each school in improving learning achievement, among others. School Review, Quality Assurance, Quality Control, Bechmarking

Based on the results of data analysis conducted on emotional intelligence variables revealed that in general students have emotional intelligence to be in a moderate category. This is evidenced by the largest percentage of students in the category being followed by the number of students who are in the high category, followed by the number of students who are in the low category. The results of data analysis on each aspect of emotional intelligence support the above results, evidenced by the large number of aspects of emotional intelligence that are in the medium category, including: (1) Recognizing self-emotions (2) Managing emotions. (3) Recognizing the emotions of others. (4) Motivate yourself (5) Build relationships

These results give an idea that although in general emotional intelligence is in a moderate category. Goleman (2014) explained that emotional intelligence is the ability to recognize our own feelings and the feelings of others, the ability to motivate ourselves, and the ability to manage emotions well in relationships with others. such as self-awareness, self-regulation, motivation, empathy, social skills.

While Goleman (Kurniawan Zulkaida, 2013) emotional intelligence is the ability to motivate one another and survive frustration, control impulses and not overestilate pleasure, regulate mood and maintain stress burdens so as not to paralyze the ability to think, empathize, and pray, use emotions 
efficiently to achieve goals, build productive relationships, and achieve success. It is also said that emotionally intelligent people will be able to recognize emotions, control emotions, motivate themselves, empathy and establish good social relationships with others. In line with the opinion of Patton (Ifham Helmi, 2002) said that emotional intelligence is the ability to use emotions effectively to achieve goals, build productive relationships and achieve success.

Other opinions were also expressed by Illahi, U., Neviyarni S, Said, Z., Ardi, Z., (2018) Emotional intelligence can put one's emotions at the right level, choose satisfaction and regulate mood. Furthermore Salovey Mayer (2010) defines emotional intelligence as the ability to recognize feelings, reach, and evoke feelings to help the mind, understand the meaning of its feelings, and control feelings deeply thus aiding emotional and intellectual development. Aspects of the aspect in emotional intelligence according to Goleman (2007) (1) recognize the emotional self, (2) manage the emotional. (3) motivate yourself. (4) recognize the emotional of others. (5) foster relationships.

There are several factors that affect a person's emotional intelligence. Goleman (2007) said that the factor that affects a person's emotional intelligence is one of them is the brain. Goleman (2007) also added factors from outside the individual's self that can influence emotional intelligence, namely the family environment and non-family environment

Based on the results of data analysis, it shows that emotional intelligence contributes to determining the level of student achievement. This result is supported by the results of research by Yanti Oktavia \& Netrawati (2019) with the results of their research that there is a correlational correlation of 0.526 . It can be interpreted that the higher the students' emotional intelligence, the higher the learning outcomes obtained by students. Furthermore, research conducted by Alwiyah (2012) where this study shows that there is an effect of emotional intelligence on student learning achievement with an influence of $41.01 \%$.

Based on the description above proves that emotional intelligence is very necessary to be improved. There are many ways to increase emotional intelligence, one of which is according to Claude Stainer who explained that there are three main steps to increase emotional intelligence including (Nggermanto, 2001): (1) Opening the heart. The central symbol of emotion is a heart that can feel comfortable at least so that the individual can start by freeing the center of those feelings from impulses and limiting influences to show love for each other. (2) Exploring the land of emotions. After opening the heart, then look at reality and determine the role of emotions in life so that it can be wiser in responding to the feelings of yourself and others. (3) Take responsibility for the problem, must dare to admit the mistakes that occur by making a mistake and decide how to change things.

Based on the results of data analysis conducted on social support variables parents revealed that in general students have social support parents who are in the moderate category. This is evidenced by the largest percentage of students in the moderate category, followed by the number of students who are in the high category. The results of data analysis on each indicator of parental social support support the above results, evidenced by the large number of indicators of parental social support in the moderate category, including: (1) instrumental support, (2) emotional support, (3) award support (4) information giving.

These results give an idea that although in general parental social support is in a moderate category, therefore the need for students to get social support from parents. The lack of social support obtained by students from parents is due to the lack of understanding and also the expectations that parents have with the advancement of student education for the future. Because parents only focus on working and meeting the needs of the family so that the support that students get from parents is only instrumental support in the form of meeting physical and material needs only while emotional support, information support and support for students are set aside so that students feel less cared for and feel uncomfortable, feel unloved. With such social support, student learning achievement can also be improved

The results of regression analysis also prove that parental social support is proven to contribute significantly to student learning prestige, so it is understandable that to improve the learning achievement of high social support of parents. 
With high parental social support, students will obtain high learning achievements can be beneficial for education and the future In simple terms it can be concluded that, if the social support of parents is improved then the student's learning achievement will increase. Conversely, if social support from parents is low, student learning achievement will decrease. The results of the study were supported by the results of research Saragi., Iswari., Mudjiran. (2016) that parental support had a $31.1 \%$ effect on students' learning achievements the remaining $68.9 \%$ was determined by other factors. Furthermore, the results of this study were strengthened by the results of Chyntia research (2019) where the results showed that parental social support directly affects student learning achievement.

This result is also in accordance with the opinion of Simarmata, (2016); Wulandari Kristiawan, (2017), that parents have an important part to help individuals achieve better success by providing compassion and education through the values of life. Parental social support provides a place for each individual to appreciate the changes that occur due to the development of maturity and teach the ability to interact (Astarini et al., 2016). (Simarmata, 2016; Wulandari Kristiawan, 2017), both religious values and social cultural values, which is a very meaningful social support for individuals (Hasgimianti et al., 2017).

Parental social support is important for every student in the education process (Maslihah, 2011; Nurhindazah Kustanti, 2016; Patty, Wijono, Setiawan, 2017), because parental social support is an interaction developed by parents characterized by care, warmth (Sarafino Smith, 2011; Dianto, 2017; Princess, Ridha, Zikra, 2017; Malwa, 2018), consent and various positive feelings of parents towards the child. Families in this case parents are the main supporters in the entire child education process (Khadija et al., 2016). Therefore, families, especially parents, are expected to take care of each other and also provide care and support to their children. If all the support students need can be met, then their perception of parental social support is also positively formed (Meiriana, 2016; Wahyuni, 2016), it also affects children's behavior and attitudes (Oktary, Marjohan, Syahniar, 2019).

In accordance with the results of the analysis that has been described, it appears that the social support of parents obtained by students from parents is still very necessary to be improved, especially with regard to attention, in addition to the indicators of social support of parents who are in the moderate category is very necessary to be improved. Support that can be provided by parents is emotional, including empathy, care, and attention given by parents to children (Fawzyah, Yulhendri, Sofya, 2019). This means that parental social support plays an important role in students' lives because their behavior depends heavily on the way they view the social support given to them (Rokhimah, 2014)

The social support provided to children is one of the aspects that has an important role in efforts to achieve children's success in their education (Purnamasari Adicondro, 2011; Putri, E.M, 2016) So it can be concluded that with high parental social support, students will not be wrong in making decisions and acting in accordance with applicable norms in order to achieve a desired goal. With such high social support, students should be able to achieve good achievements in education.

Parents need to talk to their teenage children about their problems, about their achievements, passions, and so on and let the child express their opinions (Respati, Yulianto, Widiana, 2006; Solina, Erlamsyah, Syahniar, 2013; Zarniati, Alizamar, Zikra, 2016) so that with such parental social support students will feel familiar and have friends to talk to. Therefore, parents should be able to work with the school, especially guidance and counseling teachers, to jointly improve learning achievement.

One of the most effective efforts to improve parental social support is through information services and home visits (Khadijah et al., 2016; Saragi et al., 2016). Information services can be provided during school meetings with parents, where BK teachers/counselors and principals can provide information and understanding to parents that parental social support is essential to improve student learning achievement.

Then through home visits conducted by BK Teachers / Counselors can also provide understanding to parents to improve the social support provided by parents so that students feel comfortable, loved and valued. This is in line with the opinion of Grothaus Cole (Afdal, 2015) who stated that collaborative activities with parental involvement in children's education can increase the potential for success, 
especially increased motivation, attendance level, discipline, better completion of tasks and increase the possibility to complete education on time.

\section{Conclusion}

Images of emotional intelligence and parental social support are in a moderate category. Emotional intelligence contributes significantly to a student's learning achievement. This means that the high level of student learning achievement can be explained by emotional intelligence variables. Where the higher the emotional intelligence of the student, the student's learning achievement will decrease. Furthermore, parental social support contributes significantly to student learning positions. That is, the high level of student learning achievement can be concluded that the higher the emotional support of parents, the student's learning achievement will decrease. And conversely, if social support is low for parents then student learning achievement will increase.

Emotional intelligence and orangua social support together contribute significantly to students' achievements. That is, the high level of learning achievement achieved by students is jointly influenced by emotional intelligence and parental social support. In other words, it can be concluded that the higher the emotional intelligence and social support of parents, the higher the student's learning achievement. And on the contrary, the lower the emotional intelligence and social support of parents, the lower the student's learning achievement. Emotional intelligence contributes more than a parent's social support to a student's learning achievement.

\section{References}

Abu Ahmadi dan Widodo. (2008). Psikologi Belajar. Jakarta: Rineka Cipta.

Agus Nggermanto. (2001). Quantum Quotient; Kecerdasan Quantum Cara Praktis Melejitkan IQ, EQ, dan SQ yang Harmonis. Bandung: Nuansa.

Alawiyah, T. (2012). Pengaruh kecerdasan emosional siswa terhadap Prestasi Belajar Matematika di Madrasah Tsanawiyah (MTs) Nurul Ikhwan Astanajapura Kab Cirebon (Doctoral dissertation, IAIN Syekh Nurjati Cirebon).

Astarini, D., Nirwana, H., \& Ahmad, R. (2016). Hubungan antara Konsep Diri Sosial, Persepsi Siswa tentang Dukungan Sosial Orangtua, dan Teman Sebaya dengan Komunikasi Interpersonal Siswa dan Implikasinya terhadap Pelayanan Bimbingan dan Konseli. Konselor, 5(4), 247.

Daud, F. (2012). Pengaruh kecerdasan emosional (EQ) dan motivasi belajar terhadap hasil belajar Biologi siswa SMA 3 Negeri Kota Palopo. Jurnal Pendidikan dan Pembelajaran (JPP), 19(2), 243255.

Fawzyah, F., Yulhendri, \& Sofya, R. (2019). Pengaruh Dukungan Orang Tua Dan Optimisme Masa Depan Terhadap Motivasi Beprestasi Siswa Ekonomi Sma N 2 Solok. Jurnal Ecogen, 2(2), 176186.

Goleman., Daniel. (2014). Emotional Intelligence. Jakarta: Gramedia Pustaka Utama.

Hasgimianti, H., Nirwana, H., \& Daharnis, D. (2017). Perhatian Orangtua dan Motivasi Belajar Siswa Yang Berlatar Belakang Melayu dan Jawa. Insight Jurnal Bimbingan Konseling, 6(2), 130-143.

Ifham, A., \& Helmi, A. F. (2002). Hubungan kecerdasan emosional dengan kewirausahaan pada mahasiswa. Jurnal psikologi, 29(2), 89-111.

Illahi, U., Neviyarni, N., Said, A., \& Ardi, Z. (2018). Hubungan antara kecerdasan emosional dengan perilaku agresif remaja dan implikasinya dalam bimbingan dan konseling. JRTI (Jurnal Riset Tindakan Indonesia), 3(2), 68-74.

Khadijah, K., Marjohan, M., \& Bentri, A. (2016). Kontribusi Dukungan Orangtua dan Persepsi Siswa tentang Disiplin Belajar terhadap Perilaku Membolos serta Implikasinya terhadap Layanan Bimbingan dan Konseling. Konselor, 5(3), 172. https://doi.org/10.24036/02016536553-0-00 
Kurniawan, B., \& Zulkaida, A. (2013).Contribution of emotional intelligence to autonomy of students of official college x. Proceeding PESAT (Psikologi, Ekonomi, Sastra, Arsitektur \& Teknik Sipil), 53-60.

Maslihah, S. (2011). Studi Tentang Hubungan Dukungan Sosial, Penyesuaian Sosial Di Lingkungan Sekolah Dan Prestasi Akademik Siswa Smpit Assyfa Boarding School Subang Jawa Barat. Jurnal Psikologi Undip, 10(2), 103-114. https://doi.org/10.14710/jpu.10.2.103-114

Mayer, J. D., Caruso, D. R., \& Salovey, P. (2016). The ability model of emotional intelligence: Principles and updates. Emotion review, 8(4), 290-300.

Muhibbin Syah. 2005. Psikologi Pendidikan Dengan Pendekatan Baru. Bandung: Remaja Rosdakarya.

Murphy, P.K. (2009). Cultural competence initiative. The Arlington Publics Schools.

Nurhindazah, D., \& Kustanti, E. R. (2016). Hubungan anatara dukungan sosial orangtua dengan adversity intelligence pada mahasiswa yang menjalani mata kuliah tugas akhir di fakultas teknik universitas diponegoro. Empati, 5(4), 645-652.

Oktavia, Y., \& Netrawati, N. (2019).Relationship of emotional intelligence with learning outcome of students in SMP Negeri 13 Padang. Jurnal Neo Konseling, 1(4).

Oktary, D., Marjohan, M., \& Syahniar, S. (2019). The Effects of Self-Confidence and Social Support of Parents On Interpersonal Communication of Students. Journal of Educational and Learning Studies, 2(1), 5.

Patty, S., Wijono, S., \& Setiawan, A. (2017). Hubungan dukungan sosial teman sebaya, kontrol diri, dan jenis kelamin dengan prestasi belajar siswa di SMA Kristen YPKPM Ambon. Psikodimensia, 15(2), 204. https://doi.org/10.24167/psiko.v15i2.989

Putrie, C. A. R., \& Fauzia, M. (2019). Pengaruh Dukungan Sosial Orang Tua Terhadap Prestasi Belajar Siswa SMP Angkasa Halim Perdana Kusuma Jakarta Timur. Jurnal Inovasi Pendidikan Ekonomi (JIPE), 9(2), 177-182

Respati, W. S., Yulianto, A., \& Widiana, N. (2006). Perbedaan konsep diri antara remaja akhir yang mempersepsi pola asuh orang tua authoritarian, permissive, dan authoritative. Jurnal Psikologi, $4(2), 119-138$.

Purnamasari, A., \& Adicondro, N. (2011). Efikasi Diri, Dukungan Sosial Keluarga dan Self Regulated Learning pada Siswa Kelas VIII. Humanitas, 8(1), 185-186.

Rokhimah, S. (2014). Pengaruh dukungan sosial dan efikasi diri terhadap minat melanjutkan pendidikan ke perguruan tinggi pada SMA Negeri 1 Tenggarong Seberang. Psikoborneo, 2(3), 149-156.

Sarafino, E. P., \& Smith, T. W. (1997). Health psychology biopsychosocial interaction. United State Of Amerika: John Wlley \& Sons.

Saragi, M. P. D., Iswari, M., \& Mudjiran, M. (2016). Kontribusi konsep diri dan dukungan orangtua terhadap motivasi belajar siswa dan implikasinya dalam pelayanan bimbingan dan konseling. Jurnal Koselor: Jurnal Profesi Konseling, 5(1), 1-14.

Simarmata, B. (2016). Jurnal ilmiah “INTEGRITAS” Vol.2 No. 1 Maret 2016. Jurnal Ilmiah, 2(1), 59-66.

Slameto. 2010. Belajar dan faktor-faktor yang mempengaruhinya. Jakarta: Rineka Cipta.

Sudjana, N. 1996. Rahasia Sukses Belajar. Jakarta: Raja Grafindo.

Soejanto, Agoes. 1991. Bimbingan Kearah Belajar yang Sukses. Jakarta: Rineka Cipta.

Solina, W., Erlamsyah, E., \& Syahniar, S. (2013). Hubungan Antara Perlakuan Orangtua Dengan Motivasi Belajar Siswa Disekolah. Konselor, 2(1).

Thaib, E. N. (2013). Hubungan Antara prestasi belajar dengan kecerdasan emosional. JURNAL ILMIAH DIDAKTIKA: Media Ilmiah Pendidikan dan Pengajaran, 13(2).

Tu'u, T. 2004. Peranan Disiplin Pada Perilaku dan Prestasi Siswa. Jakarta: Gramedia Widiasarana

Uno, Hamzah B. 2010. Orientasi Baru dalam Psikologi Pembelajaran. Jakarta: Bumi Aksara,

Widiyanto, M. A. (2013). Statistika Terapan: Konsep \& aplikasi SPSS/LISREL dalam penelitian pendidikan, psikologi \& ilmu sosial lainnya. Jakarta: Kompas Gramedia.

Yusuf, A. M. (2013). Metodologi penelitian:kuantitatif, kualitatif, dan penelitian gabungan. Padang: UNP Press 
Yusuf, A. M. (2014). Metode Penelitian Kuantitaif, Kualitatif dan Penelitian Gabungan. Jakarta: Prenadamedia Group

Winkel, W.S. 2009. Psikologi Pangajaran. Jakarta: Grasindo.

Zarniati, Z., Alizamar, A., \& Zikra, Z. (2016). Upaya guru bimbingan dan konseling dalam meningkatkan kegiatan belajar peserta didik. Konselor, 3(1), 12-16. 